Іміопол Інна Михайлівна,

кандиАат юриАичних наук, старший виклаАач кафеАри цивільного процесу

Національного університету "ОАеська юридична академія"

\title{
ПРЕДСТАВНИЦТВО ІНТЕРЕСІВ МАЛОЛІТНІХ ЧИ НЕПОВНОЛІТНІХ ОСІБ ПОСАДОВИМИ ОСОБАМИ ЗАКЛАДІВ ДЛЯ ДІТЕЙ-СИРІТ І ДІТЕЙ, ПОЗБАВЛЕНИХ БАТЬКІВСЬКОГО ПІКЛУВАННЯ
}

Постановка проблеми. Протягом багатьох років в Україні існує проблема порушення майнових і житлових прав Аітей уразливих категорій. Аіти які, в силу життєвих обставин, опинилися у закладах Аля Аітей-сиріт та Аітей, позбавлених батьківського піклування стикаються 3 проблемою втрати або віАсутністю власного житла чи майна й при Аосягненні повноліття або 23 років опиняються на вулиці.

Стан АосліАження теми. Аеякі аспекти Ааної проблематики були преАметом АосліАження таких науковців, як: О.І. Карпенко, О.О. Мордань, У.В. Романюк, І.А. Яніцька та ін. Крім того, варто віАмітити, що протягом 2018 року було зАійснено моніторингові візити АО ЦСПРА, притулків Аля Аітей служб у справах Аітей, інтернатних закладів Аніпропетровської, Аонецької, Закарпатської, Київської, Ауганської, ОАеської, Сумської, Харківської, Чернігівської областей під час яких було виявлено багато випадків порушення прав Аітей [1, с. 44].

Метою статті $€$ АосліАження процесуальних особливостей представництва у суді інтересів Аітей-сиріт і Аітей, позбавлених батьківського піклування.

ВикиаА основного матеріалу АосліАження 3 повним обґрунтуванням отриманих наукових результатів. Цивільне процесуальне законоАавство України містить положення щодо якого органи Аержавної влади, органи місцевого самоврядування, фізичні та юридичні особи мають право звертатись Ао суду із заявами про захист прав, свобод та інтересів інших осіб, Аержав- них або суспімьних інтересів та приймати участь у таких справах (ч. 1 ст. 56 ЦПК України).

Участь в цивільному процесі осіб, перелік яких закріплений у ст. 56 ЦПК України віАрізняється віА участі представника (наприклаА, аАвоката) тим, що вони виступають у суді в інтересах іншої особи але віА свого імені, виконуючи свої функціональні обов'язки. Конституційна реформа привнесла багато нового в розвиток судочинства, зокрема запровадивши "монополію аАвокатів", чим Аещо змінила сутність інституту преАставництва в цивільному судочинстві. Отже, на віАміну віА попереАньої реАакції ЦПК України, ч. 3 ст. 60 ЦПК України закріпила, що органи та інших осіб, яким законом надано право звертатися Ао суду в інтересах малолітніх чи неповнолітніх осіб або осіб, які визнані судом недієзАатними чи АієзАатність яких обмежена, представляють у суді їх посадові особи і це у разі якщо такі органи та особи не є стороною чи третьою особою по справі. Участь посаАових осіб у цивільному процесі вже відома судовій практиці, однак без віднесення їх до категорії осіб, які можуть бути преАставниками в суді.

Питання запобігання порушенням прав ^юАини й Аосі залишається актуальним в нашій Аержаві. Торгівля люАьми, бездомність, жебракування, Аитяча злочинність, жорстоке поводження та насильство в сім'ї, трудова експлуатація, шахрайні Аії проти люАей похилого віку та інваліАів (наприклаА, незаконне відчуження майна), порушення прав малолітніх чи неповнолітніх осіб - це Аалеко не весь перелік правопорушень на сьогодні. ВіАтак злочини проти ^юАини вимагають 
ефективних заходів їх запобігання, а мюди, які попали в скрутне становище потребують піАтримки й захисту з боку держави.

ВіАтак, зупинимось на одному з таких важмивих питань як судовий захист житлових прав Аітей-сиріт та Аітей, позбавлених батьківського піклування. Станом на 1 січня 2018 року,за Ааними Міністерства соціальної політики України, кількість малолітніх та неповнолітніх осіб, які перебувають на обліку становить 71566 Аітей, 3 них Аітей-сиріт - 21587 осіб, і Аітей, позбавлених батьківського піклування - 49979 осіб. Стаття 20 Конвенції про права Аитини гарантує право Аержавам-учасницям, відповідно Ао своїх національних законів, забезпечувати зміну Аогляду за Аитиною, яка тимчасово або постійно позбавлена сімейного оточення, шляхом направлення Ао відповідних установ по Аогляду за Аітьми. Отже, відповідно Ао ст. 18 Закону України «Про забезпечення організаційно-правових умов соціального захисту Аітей-сиріт та Аітей, позбавлених батьківського піклування" в Україні функціонують спеціальні заклади Аля Аітей-сиріт і дітей, позбавлених батьківського піклування.

ОАнак, за такими Аітьми зберігається право на житло, в якому вони проживали з батьками або рідними до встановлення опіки, піклування, влаштування в прийомні сім'ї, Аитячі будинки сімейного типу, заклаАи Аля Аітей-сиріт та Аітей, позбавлених батьківського піклування (п. 3 ч. 1 ст. 247, п. 2 ч. 1 ст. 248 СК України, п. 3 ч. 3 ст. 71 ЖК України, ст. 32 Закону України «Про забезпечення організаційно-правових умов соціального захисту Аітей-сиріт та Аітей, позбавлених батьківського піклування").

Варто звернути увагу на те, що за Ааними Міністерства соціальної політики України, станом на кінець 2017 року в Україні кількість Аітей-сиріт та Аітей позбавлених батьківського піклування нараховувала 70240 осіб, з них мають житло 47638 осіб, в тому числі на праві власності 8036 Аітей, на праві користування - 39602 особи, а не мають житла 22602 Аитини.

I саме місцеві державні аАміністрації та органи місцевого самоврядування за місцем знахоАження житла дітей несуть відповідальність за збереження житла і повернення його Аітям-сиротам та Аітям, позбавленим батьківського піклування. Заходи щодо захисту майнових та житлових прав таких Аітей зАійснюють органи опіки та піклування (ст. 231 Закону України "Про охорону Аитинства"). Крім того, віАповіАно Ао п. 57 Постанови КМУ віА 24 вересня 2008 р. "Питання Аіяльності органів опіки та піклування, пов'язаної із захистом прав Аитини" районна, районна у мм. Києві та Севастополі держадміністрація, виконавчий орган міської, районної у місті (у разі утворення) рали, сільської, селищної ради об'єАнаної територіальної громади за місцем знаходження майна забезпечує збереження майна дітей-сиріт та Аітей, позбавлених батьківського піклування, і вживає заходів Ао встановлення опіки над майном. Рішення про встановлення опіки наА майном приймається за місцем знаходження майна за поданням служби у справах дітей.

Так, наприклаА 11 ^ютого 2019 р. Попаснянський районний суА Ауганської області розглянув у судовому засіланні в порядку спрощеного позовного провадження цивільну справу за позовом Папаснянської міської раАи в інтересах неповнолітньої Аитини про визнання осіб такими, що втратили право користування житловим приміщенням. Заінтересованими особами по справі виступали виконавчий комітет Папаснянської міської рали та Служба у справах Аітей Папаснянської райдержалміністрації. Позовну заяву мотивовано тим, що позивач, віАповіАно Ао Аоговору купівлі-продажу № 1127 віА 12.12.2018 р., посвідченого нотаріально державним нотаріусом Попаснянської Аержавної нотаріальної контори ^уганської області, став власником квартири, в якій після її продажу, залишилася зареєстрована колишня власниця (віАповіАач) та ії малолітня Аитина. Аобровільно зніматися із реєстраційного обліку вона не бажає, що порушує права Попаснянської міської ради, як власника квартири. Вищевказана квартира була придбана Попаснянською міською радою Аля забезпечення житлом Аитини-сироти. Після придбання квартири, йому було видано ордер на право зайняття жилого приміщення, що підтверАжується корінцем ордеру на жиле приміщення № 7 віА 21.12.2018 р., який видано виконавчим комітетом Попаснянської міської ради. Крім того, на виконання вимог законодавства, в інтересах Аитини-сироти, Попаснянською міською радою було встановлено обтяження на вищевказану квартиру у вигляді тимчасової заборони на продаж квартири протягом 10 (Аесяти) років, що підтверджується витягом з АРРП на нерухоме майно про реєстрацію обтяження № 149386250 віА 13.12.2018 р.

Встановивши усі обставини справи та на піАставі викладеного, керуючись ст. 15, 30, 71, 72, 78, 156 Житлового кодексу УРСР, ст. 12, 19, 30, 81, 89, 263-265, 273, 274, 279 ЦПК України, суА задовольнив позов Попаснянської міської раАи 
Ао віАповідачів та визнав їх такими, що втратили право користування житловим приміщенням [2].

ОАнак, все ж таки особливої уваги потребують особи, які знаходяться в групі ризику щодо втрати житла або права на його користування через неналежне виконання службових обов'язків посаАовими особами виконавчих органів, органів опіки та піклування, з^овживання батьківськими та опікунськими правами, тощо. НаприклаА, рішеннямМарківського районного суду ^уганської області віА 16.05.2016 р. частково задоволений цивільний позов керівника Старобільської місцевої прокуратури ^уганської області в інтересах неповнолітньої особи до Служби у справах Аітей Марківської районної державної алміністрації Ауганської області про зобов'язання вчинити певні Аії, та зобов'язано сільську раду Марківського району Ауганської області подати клопотання та Аокументи необхідні Аля взяття на першочерговий квартирний облік неповнолітньої особи, як такої, що позбавлена батьківського піклування. Позов мотивований тим, що бабуся Аитини, яка була призначена опікуном за станом зАоров'я не була спроможна виконувати опікунські обов'язки, зокрема не вживала належні заходи щодо збереження нерухомого майна, внаслідок чого, відповідно до актів обстеження, стан житла визначено як незадовільний та таким, що потребує ремонту. Крім того, позивач наго^ошує на тому, що незважаючи на погіршення стану житла, посадовцями органу опіки та піклування сільської ради та служби у справах Аітей заходи щодо поновлення житлових та майнових прав Аитини не вжито [3].

Міністерство соціальної політики України, за результатами роботи у 2017 році щодо виконання основних напрямів запобігання бездомності проінформувала, що вживаються необхідні заходи щодо запобігання порушенням майнових та жит^ових прав вихованців інтернатних закладів. За звітний період (2017р.) виявлено 12 випалків порушень житлових прав та 9 випалків порушень майнових прав Аітей-сиріт та Аітей, позбавлених батьківського піклування, які виховуються в інтернатних закладах.

Зокрема, в Аонецькій області аАміністраціями інтернатних навчальних закладів проведено низку заходів, спрямованих на відновлення майнових та житлових прав вихованців інтернатних закладів. Кількість Аітей-сиріт та Аітей, позбавлених батьківського піклування, які виховуються в інтернатних закладах, житлові та майнові права яких відновлено, складає 17 осіб. У Миколаївській області районними судами задоволено позиви інтернатних закладів про визнання права власності дітей-сиріт на частку земельної Аілянки [4].

Крім того варто прийняти Ао уваги інформацію Уповноваженого Верховної Ради України з прав ^юАини про те, що в результаті моніторингових візитів у 2018 році було виявлено, що оАним із актуальних питань щодо соціального захисту Аітей $€$ забезпечення Аітей-сиріт та Аітей, позбавлених батьківського піклування, житлом. У 2018 році 3 Аержавного бюАжету місцевим бюджетам виділено субвенцію на будівництво /капітальний ремонт/ реконструкцію малих групових буАинків, будинків піАтриманого проживання, будівництво/придбання житла Аля Аитячих буАинків сімейного типу, соціального житла Аля Аітей-сиріт, Аітей, осіб 3 їх числа. Але із зазначеної субвенції було виключено категорію Аітей, позбавлених батьківського піклування (за статистикою 70\% Аітей становлять саме Аіти, позбавлені батьківського піклування), які як і Аіти-сироти за законодавством України мають такі самі права та державні гарантії. За результатами реагування Уповноваженого у Аодатку 7 Закону України № 2629-VIII віА 23.11.2018 «Про Аержавний бюджет України на 2019 рік" змінено назву субвенції та Аоповнено категорією Аітей, позбавлених батьківського піклування. Проте залишається проблема зняття 3 житлового обліку та забезпечення житлом осіб з числа Аітей-сиріт та Аітей, позбавлених батьківського піклування після досягнення ними 23-річного віку [1, с. 53].

Отже, ще один випадок бездіяльності органів Аержавної влади встановлено постановою Жовтневого районного суду м. Аніпропетровська віА 15.07.2013 р. за аАміністративним позовом особи до Олександрійської міської ради Кіровоградської області. Третьою особою в Ааній справи виступав Аиректор Аитячого будинку змішаного типу Аля Аітей Аошкільного та шкільного віку.

Свої позовні вимоги позивач обґрунтовує тим, що вона має правовий статус особи із числа Аітей-сиріт та Аітей позбавлених батьківського піклування, віАповіАно Ао Постанови Кабінету Міністрів України № 866 віА 24 вересня 2008 р. Також такий правовий статус підтверАжується рішеннями Олександрійського міськрайонного суду КіровограАської області по справі №2-3933-2005 віА 07 червня 2005 р. та по справі № 20-143-2010 віА 14 липня 2010 р. та іншими відповіАними Аокументами. Позивач була залишена своєю матір'ю без наг- 
^яду в холоАній квартирі, без їжі і віАповіАного Аогляду. Аеякий час проживала в школі-інтернаті м. Миргород, з 09 жовтня 2001 р. - проживала і виховувалась в Аитячому центрі соціальної реабілітації "Ажерело Життя" м. Олександрії, а з 18 березня 2003 р. проживала і виховувалась в Аитячому будинку змішаного типу Аля Аітей Аошкільного та шкільного віку "Нове життя", а опікуном позивача був Аиректор зазначеного Аитячого будинку, який є третьою особою у Ааній справі. 3 Аосягненням позивачем повноліття, піклування було припинено в силу положень ст. 77 ЦК України. 32005 р. позивач навчалась у Олександрійському політехнічному міцеї, який закінчила. у 2009 р. вступила до Аержавного вищого навчального закладу "Національний гірничий університет" та була тимчасово зареєстрована у гуртожитку цього навчального закладу. Після закінчення вищого навчального закладу, 31 травня 2012 р., зіткнулась 3 тим, що вона не має житла та фактично опинилась на вулиці. 24 грудня 2012 р. позивачем були направлені запити до Олександрійської міської раАи, віАповіАно Ао яких, позивач просила надати відповіАь, чи перебуває вона на квартирному обліку у Олександрійській міській раді Кіровоградської області та надати роз'яснення яким чином, можна скористатись своїм правом на забезпечення соціальним житлом. 06 ^ютого 2013 р. був отриманий мист-віАповіАь №2207 віА 21 січня 2013 р. з Олексанарійської міської раАи КіровограАської області, в якому позивачу було повідомлено, що її опікун, Аиректор Аитячого будинку змішаного типу Аля Аітей Аошкільного та шкільного віку "Нове життя" із заявою про постановлення позивача на квартирний облік та соціальний облік з метою забезпечення її після Аосягнення 18-ти років житлом, не звертався. ОАночасно було повідомлено, що на підставі ст. 1 Закону України «Про забезпечення організаційно-правових умов соціального захисту Аітей-сиріт та Аітей, позбавлених батьківського піклування" по Аосягненню позивачем 23 років вона втратила статус особи із числа Аітей-сиріт та Аітей позбавлених батьківського піклування. Зазначене свідчить про те, що з вини опікуна та служби у справах дітей позивача було позбавлено права на житло. У зв'язку з чим, та заАля поновлення свого порушеного права вона і звернулася Ао суду з Ааним позовом.

Суа задовольнив позов та зобов'язав Олександрійську міську раду Кіровоградської області поставити позивачку на квартирний облік, з урахуванням пільг встановлених Аля осіб з числа Аітей-сиріт та Аітей позбавлених батьківського піклування [5].

Отже, ст. 4 Закону України «Про органи і служби у справах Аітей та спеціальні установи Аля Аітей" гарантує представництво інтересів Аітей в судах центра^ьними органами виконавчої влаАи, що реалізують Аержавну політику у сфері усиновмення та захисту прав Аітей, а також службами у справах дітей.

Висновки з АосліАження та перспективи подальших розвіАок ц цьму напрямі. Враховуючи усе вищенаведене, зазначимо, що до представників органів та інших осіб, яким законом надано право звертатися Ао суду в інтересах малолітніх чи неповнолітніх осіб або осіб, які визнані судом недієздатними або Аієздатність яких обмежена можна віАнести посадових осіб закладів охорони зАоров'я, закладів Аля Аюдей похилого віку, заклаАів Аля ^юдей з особливими потребами тощо; осіб, в сім'ї яких проживає Аитина, батьків-вихователів будинків сімейного типу, а також посадових осіб закладів Аля дітей-сиріт і Аітей, позбавлених батьківського піклування.

\section{NITEPATYPA:}

1. Щорічна доповідь Уповноваженого Верховної Ради з прав людини за 2018 рік. URL: https://notorture.org.ua/wp-content/ uploads/2019/04/Report-2019.pdf

2. Рішення Попаснянського районного суду Луганської області від 11.02.2019 р. Справа № 2/423/1603/19. URL: http://reyestr.court.gov.ua/ Review/80131383

3. Рішення Марківського районного суду Луганської області від 16.05.2016 р. Справа № 417/2101/16-Ц. URL: http://reyestr.court.gov.ua/ Review/57687025

4. Інформація про стан виконання Основних напрямів запобігання бездомності до 2017 року URL: https://www.msp.gov.ua/ news/ 14747.html?PrintVersion

5. Постанова Жовтневого районного суду м. Дніпропетровська від 15.07.2013 р. Справа № 201/3133/13-A. URL: http://reyestr.court.gov.ua/ Review/32493950

\section{І^іопол Інна Михайлівна \\ ПРЕАСТАВНИЦТВО ІНТЕРЕСІВ МАЛОЛІТНІХ ЧИ НЕПОВНОЛІТНІХ ОСІБ ПОСААОВИМИ ОСОБАМИ ЗАКАААІВ АЛЯ АІТЕЙ-СИРІТ I АІТЕЙ, ПОЗБАВАЕНИХ БАТЬКІВСЬКОГО ПІКАУВАННЯ}

Стаття присвячена досліАженнюпроцесуальних особливостей преАставництва у суді. Аосліджено законодавче регулювання та судова практика стосовно питань преАставництва органів та осіб, яким законом надано право 
звертатися до суду в інтересах інших осіб, а саме в інтересах Аітей-сиріт та Аітей, позбавлених батьківського піклування.

Киючові слова: цивільний процес, представництво в суді, Аіти-сироти, Аіти, позбавлені батьківського піклування, неповнолітні особи, малолітні особи, житлові права.

\section{Илиопол Инна Михайловна \\ ПРЕАСТАВИТЕЛЬСТВО ИНТЕРЕСОВ МАЛОЛЕТНИХ ИАИ НЕСОВЕРШЕННОЛЕТНИХ АИЦ АОЛЖНОСТНЫМИ ЛИЦАМИ УЧРЕЖАЕНИЙ АИЯ АЕТЕЙ-СИРОТ И АЕТЕЙ, АИШЕННЫХ РОАИТЕАЬСКОЙ ОПЕКИ}

Статья посвящена исследованию процессуальных особенностей представительства в суде. Исследовано законодательное регулирование и судебная практика по вопросам представительства органов и лиц, которым законом предоставлено право обращения в суд в интересах других лиц, а именно в интересах Аетей-сирот и детей, мишенных родительской опеки.

Киючевые слова: гражАанский процесс, представительство в суде, Аети-сироты, дети, лишенные родительской опеки, несовершеннолетние лица, малолетние лица, жилищные права.

\section{Iliopol Inna \\ REPRESENTATION OF INTERESTS OF JUVENILES OR MINORS BY OFFICERS OF ORGANIZATIONS FOR CHILDREN-ORPHANS AND CHILDREN DEPRIVED OF PARENT CARE}

The article is devoted to the study of the procedural features of representation in court. The legislative regulation and judicial practice on the representation of bodies and persons who are granted the right to appeal to the law in the interests of other persons, namely in the interests of orphans and children deprived of parental care, are examined.

For many years in Ukraine there has been a problem of violation of property and housing rights of children of vulnerable categories. Children who, due to life circumstances, ended up in institutions for orphans and children deprived of parental care, face the problem of loss or lack of their own housing or property and, when they reach the age of majority or 23 years old, find themselves on the street.

The issue of preventing human rights violations is still relevant in our country. Human trafficking, homelessness, begging, child crime, abuse and domestic violence, labor exploitation, fraudulent acts against elderly people and people with disabilities (for example, the illegal alienation of property), violation of the rights of minors or minors - this is not the whole list of offenses today. Consequently, crimes against a person require effective measures to prevent them, and people who find themselves in a difficult situation need the support and protection of the state.

The civil procedural legislation of Ukraine contains a provision under which state authorities, local governments, individuals and legal entities have the right to apply to the court with statements about the protection of the rights, freedoms and interests of others, state or public interests and take part in such cases.

Key words: civil process, representation in court, orphans, children deprived of parental care, minors, juveniles, housing rights. 